ALFRED L. CASTLE

\title{
Tentative Empire: Walter Q. Gresham, U.S. Foreign Policy, and Hawai' $i$, 1893-1895
}

RECENT SCHOLARLY ASSESSMENTS of the motives of the United States in supporting the overthrow of Queen Lili'uokalani in January of 1893 by non-native, primarily American, planters, businessmen, and lawyers have emphasized economic and geostrategic positions. The United States, it is argued, was developing a strong navy to defend access to foreign markets in Latin America, Central America, Asia, and the Pacific and was seeking bases from which to protect the new navy. President Benjamin Harrison's quick recognition of Hawai'i's Provisional Government and tacit approval of the landing of American troops in apparent support of the overthrow was (the current historiographic trend has it) evidence of a new consensus in the State Department and presidency that annexation of Hawai'i was in the best interest of business.

President Grover Cleveland and his secretary of state, Walter Q. Gresham, are widely credited with revoking Harrison's treaty of annexation, which had been hastily negotiated with a delegation of commissioners from Hawai'i's Provisional Government. But few historians have investigated the depth or nature of Secretary of State Gresham's opposition to annexation and to the Provisional Government's very existence. ${ }^{1}$ More significantly, few have reviewed the impact his principled opposition to the Provisional Government had on events in Hawai'i from 1893 to 1895 . Going beyond the cautious

Alfred L. Castle is vice-president for university advancement at California State University at San Marcos.

The Hawaiian Journal of History, vol. 29 (1995) 
and often ambiguous anti-imperialistic position of President Cleveland, Gresham sought to undo the work of the Provisional Government and the succeeding Hawaiian Republic. An analysis of Gresham's rather astonishing independent actions to undo the overthrow of the queen reminds us how tentative, even contradictory, U.S. foreign policy was with respect to Hawai' $i$ in the period 1893-1895.

Gresham (1832-1895), born in Lanesville, Indiana, was a largely self-educated attorney. Rising in the ranks of Indiana judges, he served honorably as a Civil War general and later as secretary of the treasury and postmaster general under Republican Gilded Age presidents. Breaking with the Republicans over protective tariffs, and his personal animosity to Benjamin Harrison, a political rival and the successful Republican candidate for the presidency in 1888 , he accepted Cleveland's offer to serve as secretary of state in 1893 . The Hawaiian delegation to Washington which petitioned Secretary of State John W. Foster for annexation found Gresham to be a "dark and vengeful man" who, having prejudged the Provisional Government's case, was determined to reverse the outcome of the revolution. ${ }^{2}$

Like many of Cleveland's cabinet officers, Gresham was a staunch anti-imperialist. Typical of other prominent white, Anglo-Saxon, Protestant anti-imperialists, he held a strong belief in the traditional political values of liberty, political equality, and self-determination. Wishing to preserve the political values and foreign policy of the late eighteenth century, he argued that the constitution did not provide for colonial acquisition. Overseas territories would require huge military expenditures and increased taxes, would drag the United States into needless wars, and would violate the nonentanglement position of Washington's Farewell Address and Jefferson's First Inaugural. Most significant for Gresham, imperialism and colonialism, as demonstrated in the Harrison administration efforts to annex Hawai' $i$, clearly illustrated the moral dangers inherent in denying self-rule to subject peoples and in violating the essential American principle that governments derive their legitimate powers from the consent of the governed. ${ }^{3}$ Rejecting the argument of Hawai'i's postrevolutionary Provisional Government that the revolution occurred because Queen Lili'uokalani tried to remove the necessary constitutional limits on arbitrary royal authority (and thus the revolution was defensive), he 


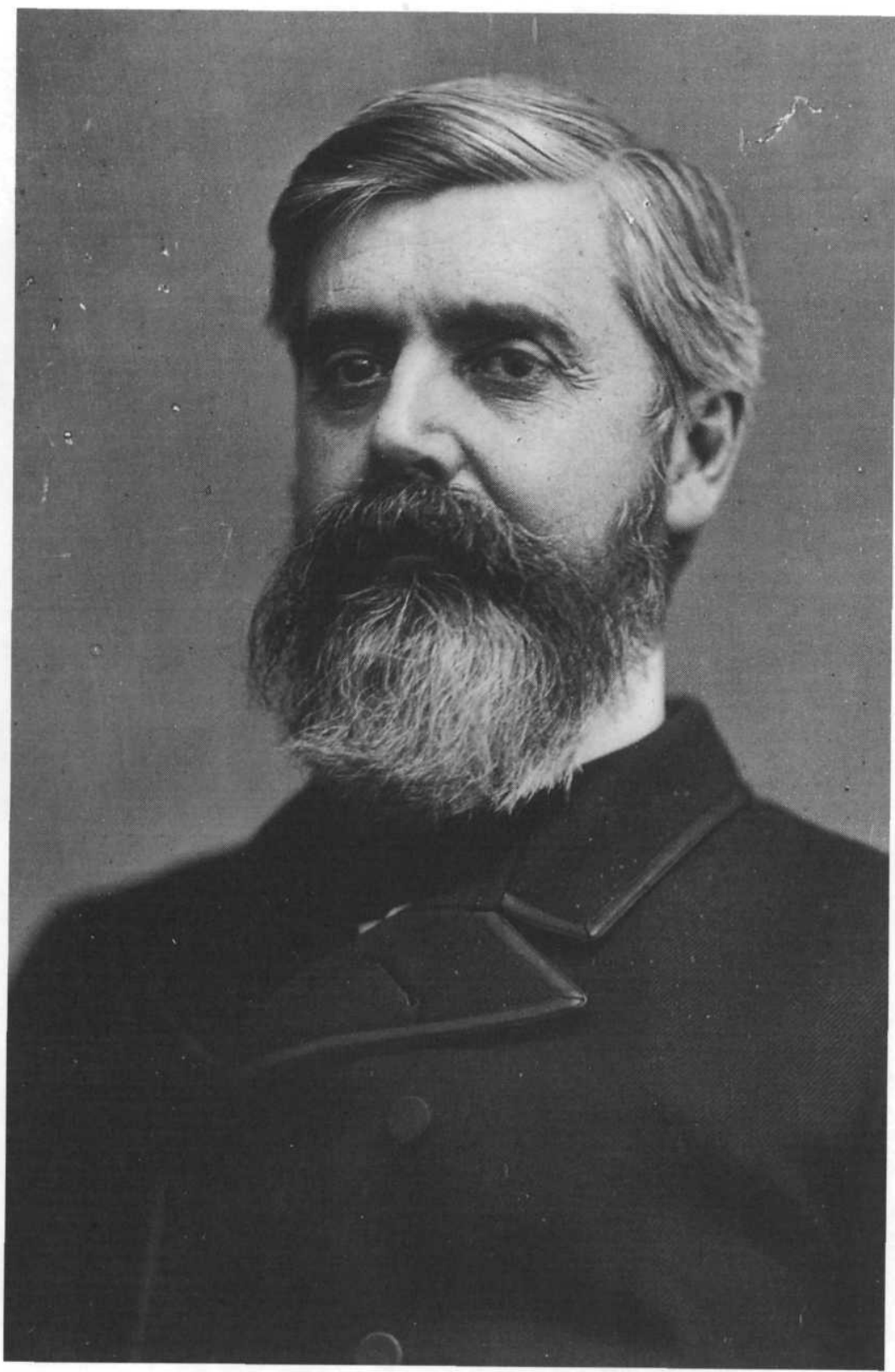

FIG. 1. Walter Quintin Gresham $\left(183_{2-1895}\right)$ of Indiana was Grover Cleveland's secretary of state from 1893 to 1895 , capping a career that included service as postmaster general, secretary of the treasury, and as a U.S. circuit judge. (Library of Congress LC-BH826-1435.) 
vowed to undo an outcome guaranteed by U.S. military intervention. In taking this position, Gresham differed from most members of Harrison's diplomatic corps, who were convinced by delegates W. R. Castle, Sr., and Lorrin Thurston that the queen's interference with the 1887 constitution-not the plural and contradictory sugar interests-caused the revolution. ${ }^{4}$

Gresham's efforts to block annexation and to unseat the revolutionaries began with his failed orchestration of the government's attempts to restore the queen in 1893 . Convinced by periodic reports from President Harrison's representative, James Blount, that the Provisional Government had been imposed on Hawaiians without their consent and that only a small minority favored annexation, he argued that the United States had disastrously supported an unjust revolution and should undo what it had done. ${ }^{5}$

In November and December of 1893 , Gresham advocated the restoration of the queen if she would meet Cleveland's condition that she pardon the revolutionaries. When the new U.S. minister to Hawai' $i$, Albert S. Willis, failed to get the queen's quick and unambiguous agreement to this condition, Gresham and his supporters in the press and Congress lost the opportunity (which was always slight) to restore the queen by force of arms. Cleveland also believed that U.S. interference in the revolution of January 1893 was "disgraceful," but was far more reluctant to force the issue of restoration than was Gresham. ${ }^{6}$ Though respectful of Gresham's high-mindedness and intelligence, he turned the matter of restoration over to the Democratically controlled Congress for action. Significantly, Cleveland's difference with Gresham over the use or threat of force to restore the queen appears to have occurred because of a different view of American expansionism. ${ }^{7}$ (Indeed, in part because of their differences over the role of U.S. influence overseas, Cleveland made Gresham his secretary of state only after two others had refused the office. $\left.{ }^{8}\right)$ Whereas Gresham was a pure anti-imperialist who feared the consequences of any undue U.S. influence overseas, Cleveland desired a continuing sphere of influence in Hawai' $i$. The kingdom, as he saw it, would best serve U.S. interests by remaining politically independent but amenable to economic and military dependence on an industrializing U.S. economy. He advocated continuing the 1842 Tyler Doctrine, which had prevented European hegemony in Hawai' $i$ while refusing to limit 
future U.S. domination. ${ }^{9}$ Toward that end, he had not objected to the coercive negotiations with King Kalākaua in 1884 which led the United States to acquire exclusive rights to develop Pearl Harbor as a future naval base. ${ }^{10}$

Cleveland was pleased to pass the controversial matter of the restoration of the queen on to Congress when it reconvened on December 4, 1893. Gresham, however, wanted to go further and quietly encouraged key Democratic leaders of the House of Representatives to embarrass the Republicans by disavowing American minister John L. Stevens's use of troops to restore Lili'uokalani. After much loud debate, the House passed a resolution deploring the actions of Stevens, denying the possibility of annexation, and reaffirming the U.S. preference for noninterference in the purely domestic affairs of other countries. ${ }^{11}$

In the Senate, Gresham urged anti-imperialist Senator John M. Palmer to make a strong moral and legal argument for restoration. He had unsuccessfully made the same request to Cleveland when he wrote

should not the great wrong done to a feeble but independent state by an abuse of authority of the U.S. be undone by restoring the legitimate government? Anything short of that will not, I suspect, satisfy the demands of Justice. ${ }^{12}$

Again going beyond the interests of the president, Gresham promised Palmer that the State Department would cooperate with the Senate to get the facts necessary for a strong resolution for restoration. ${ }^{13}$ Gresham was particularly concerned whether the powerful Republican minority in the Senate would prevent a call for restoration. More important, the Senate Democrats, unlike their colleagues in the House, were divided over what action to take. For example, the chairman of the Foreign Relations Committee, Alabama Senator John T. Morgan, was sympathetic to annexation and enjoyed the company of Lorrin Thurston, the loquacious representative from Hawai'i's Provisional Government. Morgan held six weeks of hearings and concluded that Blount had made numerous errors in his investigations in Hawai' $i$; therefore no conclusions about the viability or popularity of the overthrow could be reached. (Blount objected to U.S. troops 


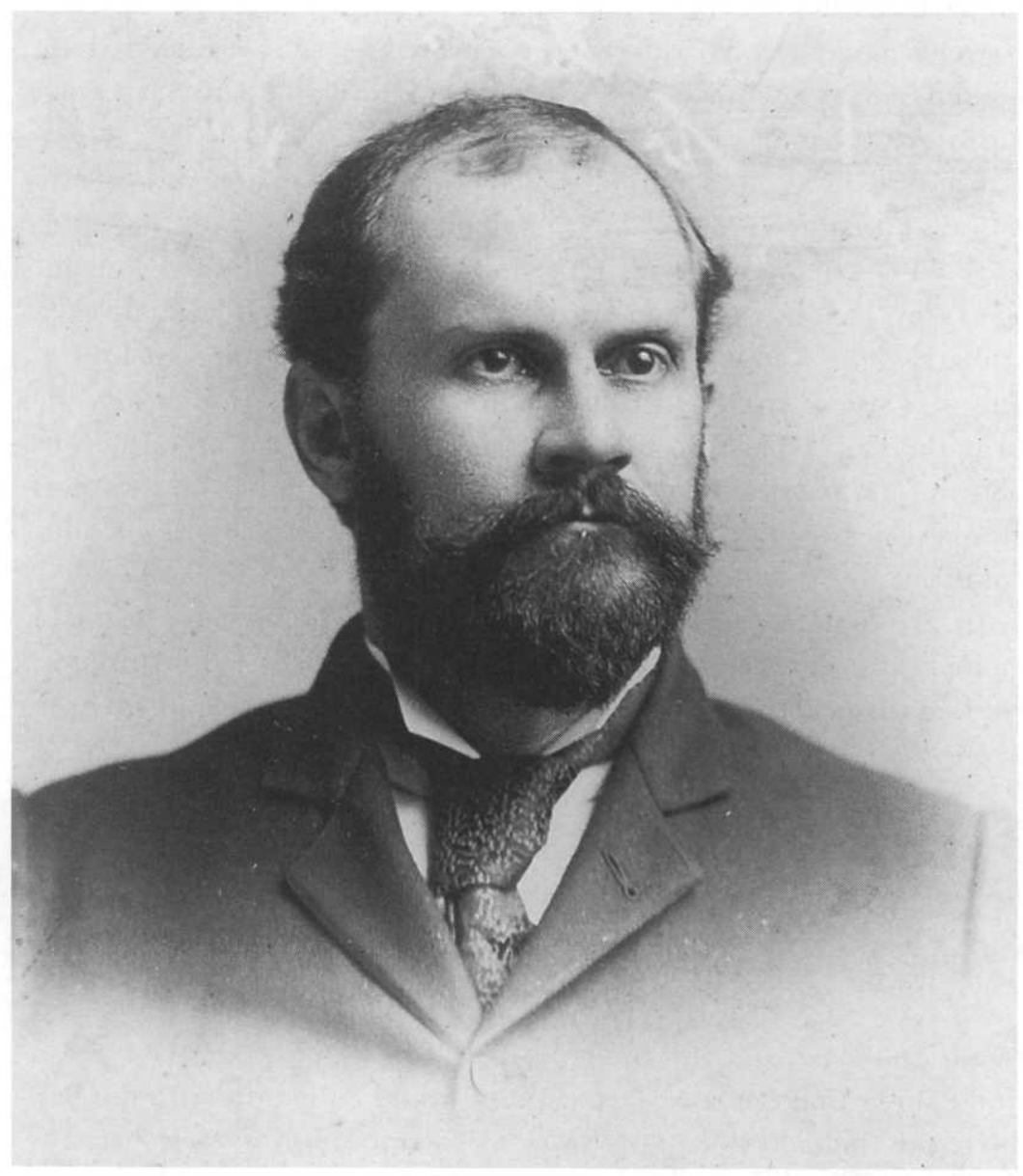

Fig. 2. Lorrin Andrews Thurston (1858-1931), as Provisional Government envoy to Washington after the 1893 overthrow, helped prepare the way for U.S. annexation of Hawai'i. (Hawaiian Mission Children's Society.)

being landed to maintain order, remembering how his native Georgia had been occupied against the will of most Georgians after the Civil War.) Morgan also declared that restoration would violate U.S. preferences for republics over monarchies. As he put it,

When a crown falls, in any kingdom of the Western Hemisphere, it is pulverized, and when a scepter departs, it departs forever, and Ameri- 
can opinion cannot sustain any American ruler in the attempt to restore them, no matter how virtuous and sincere the reasons may be that seem to justify them.

He further concluded that "all intelligent men in Hawaii and the U.S., who had taken the pains to consider the subject," favored annexation because of the strategic and commercial advantage of Hawai'i. ${ }^{14}$

While no other senator supported Morgan's blunt statement, the Senate, concerned that the majority of the public would not condone the use or threat of force to restore a monarch, failed to agree with the House's resolution. Instead, it called for the people of Hawai'i to decide their own political fate. The failure of restoration frustrated Gresham, who felt Lorrin Thurston had exercised undue influence over Morgan and others. ${ }^{15}$ Nonetheless, Gresham was pleased that annexation was dead and the impropriety of Harrison's actions had been laid bare. To bolster his convictions, he wrote to a host of influential friends, arguing that an intellectual case against annexation would make it less likely to happen in the future. In addition to the immorality of annexation, Hawai' $i$ was, he claimed, numerically dominated by non-Anglo-Saxons who by intellect and temperament were not capable of the rigors of self-rule; honest self-rule could occur only when Teutonic peoples organized politically. ${ }^{16}$ If Hawai' $i$ were annexed by the United States, it would ensure the incorporation of a politically incapable and despotic people. ${ }^{17}$

Frustrated in his attempt to restore the queen, Gresham faced the unhappy prospect of conducting normal diplomatic relations with the Provisional Government. Given to passionate dislikes and suspicious of the motives of his past political rivals, Gresham clearly planned to make normal transactions as difficult as possible for Hawai'i's representatives. Seeing no moral ambiguity in the action of the revolutionaries and furious that Thurston and others had escaped the consequences of their actions, he could only depend on his ability to manipulate Cleveland and to undermine the viability of the Provisional Government. ${ }^{18}$

By the spring of 1894 , Gresham worried that the unstable Provisional Government might be solidified and made more acceptable if it devised a more permanent constitution. When he heard the Provi- 
sional Government was attempting to do just that by calling for a constitutional convention, he wired U.S. minister Albert Willis to warn that American citizens who participated in such an outrage might lose the right of protection from the United States. Although Willis did not get this bizarre warning out to American citizens before the constitutional elections, he reported the alarm of many Americans who had voted. ${ }^{19}$ Moreover, when Willis refused to grant full recognition to the new Hawaiian Republic when it was declared on July 4, 1894 (although Cleveland did extend official recognition that August), Gresham criticized him for offering provisional recognition when no recognition at all should have been offered.$^{20}$ Gresham's unusual application of high moral standards in judging the legitimacy of a foreign regime predated and anticipated the better-known attempts of Woodrow Wilson to deny recognition to countries not meeting standards of morality as he defined them. Gresham's failed attempt to break with the traditional American diplomatic practice of de facto recognition for governments in control of their population and meeting all financial and diplomatic obligations is a neglected aspect of U.S. diplomatic history.

As significant as the denial of traditional recognition was Gresham's petulant and sudden recalling of an American war vessel, the Philadelphia, assigned to Honolulu. Under the direction of Admiral John G. Walker, the warship had given additional confidence to Sanford Dole and the leaders of the nascent Hawaiian Republic. Moreover, to the distress of Gresham, Admiral Walker, who favored annexation for strategic reasons, continued to send reports of internal conditions to the like-minded secretary of the navy, Hilary Herbert. Herbert's periodic contacts with Congressional leaders were viewed as a distinct threat to the Cleveland-Gresham plan to prevent annexation. To the dismay of Gresham, Walker struck up a friendship with Dole, entertained him and members of his cabinet on board ship, and eventually obtained permission for U.S. marines to drill in Honolulu. This did not disturb Cleveland, who, unlike the secretary of state, was comfortable with Walker's role and with an implied protectorate over Hawai' $i$ which might discourage Japan and Britain from seizing the Islands. Nonetheless, Cleveland was talked into recalling Walker on August 2, 1894, on the premise that the admiral had exceeded his authority by not allowing Willis the sole right to 
provide political information to Washington and negotiate with the Republic. Walker was reprimanded and no replacement was named. ${ }^{22}$ Thus, an important implied military commitment to the Republic had been removed. ${ }^{23}$

In early August, Gresham welcomed a delegation of the queen's supporters to the State Department. H. A. Wildeman, J. A. Cummins, and Samuel Parker, former royalist cabinet members, discreetly inquired what Gresham's position would be if a coup was organized to restore the queen. Gresham, seeing a chance to accomplish what his own maneuvering had failed to do, assured the delegation that "you will encounter no opposition from this government. We claim no right to meddle in the domestic affairs of your country." ${ }^{44}$ Moreover, he told Samuel Parker a few days later, "our warships were sent to Hawaii not to uphold the Provisional Government or its successor, but to afford protection to such of our citizens as did not participate in the local strifes." ${ }^{25}$ Although Cleveland would not consent to aid the coup, no attempt to block it would be made.

Throughout the fall of 1894 , rumors flew in Honolulu regarding the possibility of a U.S.-sanctioned coup to overthrow the Republic. The rumors were fueled by the fear of Gresham's known antipathy to the leaders of the Republic, particularly Lorrin Thurston. Although U.S. minister to Hawai'i Albert Willis generally discounted these rumors as anti-Cleveland propaganda, he did wire Gresham on November 10 to report gossip about arms being shipped to royalist conspirators from San Francisco. After discussions with various State Department assistants as well as the Hawai'i chargé d'affaires, Frank Hastings, Gresham decided that Willis was unduly concerned and had acted rashly in even suggesting a U.S. investigation. Writing Willis, he justified State Department inaction by asserting that "Hawaii is not at war with any other power, we have no information of an insurrection against the present government, and we know of no statute which would authorize the President or the head of any Department to stop the shipment of arms from San Francisco." Since Hawai'i was a neutral country, it would need to enforce its own neutrality. ${ }^{26}$

In early January 1895 , royalist forces led by Robert Wilcox staged a revolt that lasted three days and killed three people, including Republican leader Charles L. Carter. ${ }^{27}$ Upon word from Willis that the rumors of the arms shipment from San Francisco were true and 
the revolt had not been broadly supported by the native Hawaiian population, President Cleveland immediately sent the warship Philadelphia back to Honolulu. Under Admiral L. A. Beardslee, the U.S. military forces were limited to the traditional role of protecting lives and property while avoiding assistance to either side in a purely domestic dispute.

Fearful that New England Republican senators like Henry Cabot Lodge would use the coup as ammunition against Cleveland and his anti-annexationist position, Gresham chose to attack first. Working with his closest ally in the Democratic party, Texas Senator Roger Q. Mills, Gresham advised Democrats to prevent the possibility of a renewed annexationist movement by suggesting that certain New England Republican senators had a conflict of interest. Specifically, Gresham claimed that well-connected leaders of Hawai'i's Republic, men such as Lorrin Thurston and William R. Castle, Sr., had exercised undue influence on their Congressional friends and could count on automatic support for annexation. Moreover, Gresham urged Mills to charge that New England Senate friends of the Republic held Hawaiian government bonds whose value would increase if Hawai' $i$ became part of the United States. ${ }^{28}$ To round out the preemptive attack, Gresham urged Mills to appeal to America's working class by revealing how much Hawai'i's sugar plantations relied on imported, exploited, and degraded laborers from Asia. This argument, combined with an ongoing criticism of the unrepublican features of the new Republic would, Gresham felt, forestall any movement on the part of Congress to embarrass the Cleveland administration for its unpreparedness in the coup. ${ }^{29}$

Not content to prevent Congressional disfavor, Gresham moved forcefully to interfere with the trials of the Hawaiian insurrectionists. He instructed the hapless Willis to protest against capital punishment for the rebels, saying those claiming U.S. citizenship should have their trials and verdicts reviewed by American authorities. Willis was further advised to threaten the use of troops from the Philadelphia if copies of all trial proceedings against U.S. citizens were not produced in a timely fashion.

Under the Republic's declaration of emergency martial law, the writ of habeas corpus was suspended. When Willis reported that a number of aliens supporting Robert Wilcox had been arrested and held without bail, Gresham ordered Willis to protest loudly. To what 
extent Gresham's independent action, in defiance of American principles of nonintervention in the affairs of an independent state, moderated the sentences eventually handed out to the insurrectionists is not known. As W. O. Smith wrote Thurston, who was in Washington, many leaders of the Republic desired strong sentences to serve as an example to those who might consider revolt in the future. Moreover,

Willis is determined to protect the Royalists. He does not seem to see the inconsistency in view of Cleveland's instructions not to protect those participating! As we analyze the facts and evidence, the guilt goes back to Cleveland, who has held out to the Hawaiians that the monarchy is the rightful government here, and ... should be restored. Cleveland and Liliuokalani are the most guilty. Sometimes it seems horribly wrong to think of executing Kanakas and not Liliuokalani and Grover. Damn him! ${ }^{30}$

Though Smith names Cleveland in his letter, it was clearly Gresham who, opposing what he considered a fraudulent government, drove U.S. policy to moderate the consequences of the failed coup attempt.

In a final battle to undermine and discredit the Republic, Gresham managed to deflect Thurston's charges regarding U.S. complicity in the Wahlberg affair. Under the direction of a German captain, the Wahlberg had delivered arms from San Francisco to the rebels in Hawai 'i. Despite substantial evidence provided by Hawai'i's minister to the United States, Thurston, Gresham refused to take action against the ship's owners. Seeing a chance to discredit Gresham in Congress, Thurston leaked information of this nonfeasance to the U.S. press. When the New York Herald first broke the story on February 13, 1895, Gresham discovered the source of the leak and demanded Thurston's recall as Hawai 'i's representative. ${ }^{31}$ After the frustration of not being able to dislodge the Hawaiian Republic, Gresham could at least eliminate the most odious of its representatives. ${ }^{32}$ Shortly before his death from pneumonia on May 28, 1895, he confided to close friends that "I still have confidence in the ultimate triumph of the right. I believe that when the American people fully understand the Hawaiian matter, they will condemn the great wrong done the natives by the missionaries and their descendants, supported by the U.S." ${ }^{33}$

Gresham was, of course, ultimately unsuccessful in preventing annexationist sentiment from growing, which it rapidly did after the 
1896 election of William McKinley. He was, however, able to delay action and shape Cleveland's Hawaiian policy. His extraordinary efforts to depose the Provisional Government and to, at least indirectly, encourage a coup against the Republic were inconsistent with his policy of nonintervention. Despite the American public's unwillingness to restore a monarch, Gresham remained tenacious in his purpose and in his sense of moral rectitude. The combination of national anti-imperialism with personal motives of revenge against those who opposed him in Congress and in Hawai' $i$ weakened his influence in the Democratic party, embarrassed Cleveland on several occasions, and gave Republicans like Henry Cabot Lodge and Theodore Roosevelt issues to exploit. Anti-imperialism, still popular with large numbers of Americans, had been somewhat discredited by its erratic application by Gresham in the period 1893-1895. Perhaps most importantly, a review of Gresham's independent course reminds us how awkwardly, how tentatively, the United States began its experience with imperial acquisition.

\section{Notes}

${ }^{1}$ For the predominant accounts of U.S. motivation in the annexation, see Robert Beisner, Old Diplomacy to the New, I865-19oo, 2nd ed. (Arlington Heights: U of Illinois P, 1986); Lloyd C. Gardner, Economic Aspects of New Deal Diplomacy (Madison: U of Wisconsin P, 1964); David F. Healy, U.S. Expansionism: The Imperialist Urge in the I89os (Madison: U of Wisconsin P, 1970); Walter LaFeber, The New Empire: An Interpretation of American Expansion, 1860-1898 (Ithaca, N.Y.: Cornel UP, 1963); Walter LaFeber, The American Age: U.S. Foreign Policy at Home and Abroad, 2nd ed. (New York: Norton, 1994); A. P. Thornton, Doctrines of Imperialism (New York: Wiley, 1965); Robert W. Tucker, The Radical Left and American Foreign Policy (Baltimore: Johns Hopkins UP, 1971). For representative traditional accounts of the overthrow, see William R. Castle, Jr., "John W. Foster," in The American Secretaries of State and Their Diplomacy, ed. Samuel F. Bemis (New York: Alfred A. Knopf, 1928) 210-19; W. R. Castle, Sr., "American Annexation of Hawaii," in Reminiscences of William R. Castle Sr. (Honolulu: Privately Printed, 1960); and Albert Taylor, Under Hawaiian Skies (Honolulu: Advertiser Publishing Co., 1926).

${ }^{2}$ See Diary of W. R. Castle, Sr., entries for 9-1o Mar., 13-14 Mar., and 16 Mar. 1893, Pacific Collection, Hamilton Library, University of Hawai'i at Mānoa. Much of his opposition to the Provisional Government was widely rumored in Washington to be due to his long-standing dislike of Harrison, a fellow Indiana politician.

${ }^{3}$ For a summary of the anti-imperialist arguments, see Robert I. Beisner, Twelve 
Against Empire: The Anti-lmperialists, I898-19oo (New York: McGraw-Hill, 1968), and E. Berkeley Tompkins, Anti-Imperialism in the United States: The Great Debate, I890-1920 (Philadelphia: U of Pennsylvania P, 1970).

${ }^{4}$ William R. Castle, Jr., Hawaii Past and Present (New York: Dodd, Mead, 1923) 49-5o. See also Merze Tate, Hawaii: Reciprocity or Annexation (East Lansing: Michigan State UP, 1968) 249.

${ }^{5}$ Lorrin A. Thurston, Memoirs of the Hawaiian Revolution, ed. Andrew Farrell (Honolulu: Advertiser Publishing Co., 1936); letter, Walter Gresham to Carl Schurz, ${ }_{4}$ Sept. $188_{3}$, Schurz Papers, Library of Congress.

${ }^{6}$ Letter, Cleveland to Richard Olny, 8 July 1898 , in Letters of Grover Cleveland, 1850-19o8, ed. Allan Nevins (Boston: Houghton Mifflin, 1953). See also Rexford Tugwell, Grover Cleveland (New York: Macmillan, 1968) 245.

${ }^{7}$ Gresham's intransigence and prickly personality actually hurt the anti-expansionist position by alienating the press which deplored annexation and restoration. See Thomas J. Osborne, Empire Can Wait: American Opposition to Hawaiian Annexation, I $893-1898$ (Kent, Ohio: Kent State UP, 1981) 59. The leading recent biographer of Gresham believes Gresham's idealism and appeal to a vague international morality were sincere, even if often misapplied and self-defeating. See Charles W. Calhoun, Gilded Age Cato: The Life of Walter Q. Gresham (Lexington: U of Kentucky P, 1988).

${ }^{8}$ George F. Parker, Recollections of Grover Cleveland (New York: Century, 19o9) 178. See also Horace S. Merrill, Bourbon Leader: Grover Cleveland and the Democratic Party (Boston: Little, Brown, 1957).

${ }^{9}$ Lester B. Shippe, "Thomas Francis Bayard," in The American Secretaries of State and Their Diplomacy, ed. Samuel F. Bemis (New York: Alfred Knopf, 1928) 8283 . Cleveland strongly criticized Bismarck's analogizing German aggression in Samoa with American actions in acquiring exclusive use of Pearl Harbor.

${ }^{10}$ Allan Nevins, Grover Cleveland: A Study in Courage (New York: Dodd and Mead, 1964) 553 .

11 Congressional Record, 53rd Cong., 2nd sess., 127-31, 189-9o, 196-98, 204-o6, $1594,1813-22,1879-89,194^{2}-72,2000-08,2281-91,313^{8}-39$.

12 Letter, Gresham to Cleveland, 3 Dec. 1893 , in Robert McElroy, Grover Cleveland: The Man and the Statesman, vol. 2 (New York: Harper Brothers, 1923) 60.

13 George R. Dulebohn, Principles of Foreign Policy under the Cleveland Administration (Philadelphia: U of Pennsylvania P, 1941) 43.

${ }^{14}$ Senate report 227, 53rd Cong., 2nd sess., 401-02, 406-07, 409, 411-14.

15 Thurston, Memoirs 473-74.

${ }^{16}$ Gresham had opposed suffrage for blacks after the Civil War and had thus alienated peaceful Republican leaders like Charles Sumner. See Montgomery Schuyler, "Walter Q. Gresham," in The American Secretaries of State and Their Diplomacy, ed. Samuel Flagg Bemis (New York: Alfred A. Knopf, 1928) 236.

${ }^{17}$ See Alfred L. Castle, "Advice for Hawaii: The Dole-Burgess Letters," HJH ${ }_{15}$ (1981): 24-31.

${ }^{18}$ Letter, Harrison to Foster, 1 May 1893 , John W. Foster Papers, Library of Congress. Gresham was convinced that Cleveland could be manipulated through excessive and fulsome praise. To get Cleveland to agree with him, he often con- 
vinced the president that he had originated ideas Gresham held to. John Bassett Moore, memorandum of a conversation with Gresham, 4-6 May 1894, Moore Papers, Library of Congress.

19 Thurston, Memoirs $55^{2}$.

${ }^{20}$ Letter, Gresham to Willis, 27 July 1894, Albert S. Willis Papers, Felson Club, Louisville, Kentucky.

${ }^{21}$ Ironically, Admiral Walker interfered in Hawaiian politics as much as Minister John L. Stevens had. Frequently claiming to have secret and broad authority from President Cleveland, he refused to deny the local newspaper reports that his mission was intended to prevent a royalist coup or aggression against Hawai' $i$ from Japan or Britain. Recommending a greater U.S. military presence in Hawai' $i$, he conducted the most extensive survey of Pearl Harbor yet made. See William M. Morgan, "Strategic Factors in Hawaiian Annexation" (Ph.D. diss., Claremont Graduate School, 1980) 89-9o.

${ }^{22}$ Letters, Gresham to Willis, 12 May, 22 July, 27 July, 31 Aug. 1894, Albert Willis Papers.

${ }^{23}$ Gresham may have convinced Cleveland to support him because of Japan's decreased interest in Hawaiian matters due to the Sino-Japanese War of 189495. Japanese warships left Hawaiian waters, and Japan failed to challenge the provision of the Hawaiian Republic's constitution which denied the franchise to Japanese residents of Hawai' $i$. The Republic experienced economic recovery after the Wilson-Gorman Tariff (August 1894) restored the advantages of the 1887 Reciprocity Treaty for Hawaiian sugar and ended the domestic bounty provided for in the 1890 McKinley Tariff. Walter LaFeber, The American Search for Opportunity, 1865-1913 (New York: Cambridge UP, 1993) 91-95, 118-21.

${ }^{24}$ Memoranda of conversations between Gresham and H. A. Wildemann, 2 Aug. 1894. General Records of the Department of State, Miscellaneous Memoranda, Record Group 59, National Archives.

${ }^{25}$ Conversation of Gresham with Parker, 5 Aug. 1894. General Records of the Department of State, Miscellaneous Memoranda.

${ }^{26}$ Letter, Gresham to Willis, 19 Nov. 1894 , Albert Willis Papers.

${ }^{27}$ For details, see William Adam Russ Jr., The Hawaiian Republic (I 894-98) and The Struggle to Win Annexation (Selinsgrove, PA: Susquehanna UP, 1961) 49-92.

${ }^{28}$ A similar claim had been made in the 184 os when those favoring annexation of Texas were charged with holding the Texas Republic's government bonds.

${ }^{29}$ Congressional Record, 53d Cong., 3rd Sess., 1133-39, 1167, 1170-74, 1200 , $1205^{-13}, 1277-83,1329-36,1408-12,1460$. See also Calhoun, Gilded Age Cato $15^{8-59}$.

${ }^{30}$ Letter quoted in Thurston, Memoirs 529 .

31 Thurston, Memoirs 537-38, 557-6o.

32 Thurston, not wanting to alienate Cleveland, quickly agreed to return to Honolulu. There, he returned to private life, refusing an offer by Dole to become the Republic's foreign minister, in order not to hinder future attempts for annexation. Thurston, Memoirs $560-62$.

${ }^{33}$ Quoted in Calhoun, Gilded Age Cato 161. 